\title{
CARrots OR CANDY IN CORNER STORES?: FEDERAL FACILITATORS AND BARRIERS TO STOCKING HEALTHIER OPTIONS
}

\author{
Sheila Fleischhacker, PhD, JD* \& Joel Gittelsohn, PhD, MS**
}

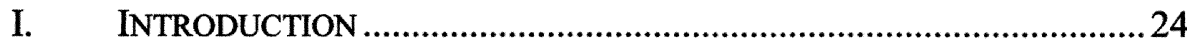

II. FISCAL FACETS OF FEDERAL FOOD AUTHORITY ................................30

A. Commerce Clause ................................................................. 31

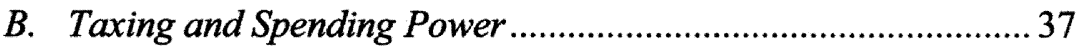

III. FROM PRODUCTION TO PROMOTION .................................................43

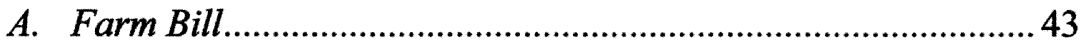

B. Healthy Food Financing Initiative............................................ 45

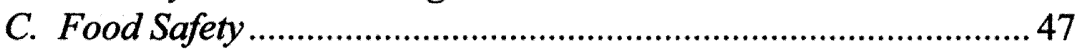

* Sheila Fleischhacker is a National Institute of Health-University of North Carolina Interdisciplinary Obesity Post-Doctoral Fellow. Her current research interests include the role of the built environment in childhood obesity and health disparities. Specifically, she is working with Alice Ammerman, Kelly Evenson, and Daniel Rodriguez on developing a methodology examining the emergence, employment, effectiveness, and encouragement for policy implication in obesity research articles focused on school-level factors (e.g., walk-toschool options, school food availability within the lunchroom, school campus, and immediate school neighborhood, and school health policies). Sheila is also working with this team, Amy Ries, and the NC Commission on Indian Affairs, to investigate access to healthy eating in NC American Indian communities. In addition, she works with the Society for Nutrition Education, two alliances, and Congressional members on 2009 Child Nutrition Reauthorization. This includes various reports, position statements, and bill language. Sheila received a B.S. and J.D. with a Certificate in Health Law from Loyola University Chicago and Ph.D. in Integrative Biosciences/Nutritional Sciences from The Pennsylvania State University. She has written an array of scientific publications, policy briefs, and law reviews on a range of topics including childhood obesity, health disparities, research ethics, and food safety. Her professional experiences include: The Government Accountability Project, Obama for America, Rush University Medical Center Office of Legal Affairs, Illinois Office of the Attorney General Environmental Division, Illinois State Board of Education Nutrition Programs, PowerBar/Nestle, and the American Indian Housing Initiative. She is licensed to practice in Illinois.

** Joel Gittelsohn, PhD, MSc, Associate Professor, Department of International Health, Johns Hopkins University, is a medical anthropologist who specializes in the use of qualitative and quantitative information to design, implement and evaluate health and nutrition intervention programs. Dr. Gittelsohn integrates qualitative and quantitative approaches to better understand culture-based beliefs and behaviors regarding dietary patterns, and how these factors influence the success or failure of dietary and lifestyle modification strategies. He applies these methods and interventions for the prevention of obesity and diabetes among different indigenous and ethnic groups, to nutrient deficiencies of Nepalese children and women, and to improve infant feeding in diverse settings (The Gambia; Hartford, CT; Peru). $\mathrm{He}$ is currently working on chronic disease interventions among the White Mountain and San Carlos Apache (obesity prevention), the Ojibwa-Cree (diabetes prevention), African American church-going women (cardiovascular disease prevention) and children and adults in the Republic of the Marshall Islands (obesity and undernutrition prevention). He received his B.A. from the University of California at Berkley; M.S. from the University of Connecticut; and his Ph.D. from the University of Connecticut. For more information, go to www.healthystores.org. 
D. Child Nutrition Reauthorization ..................................................49

E. Food Marketing ………………...............................................5

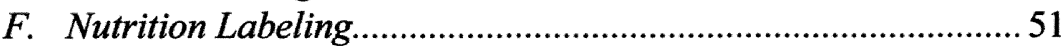

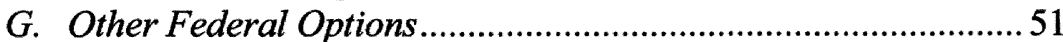

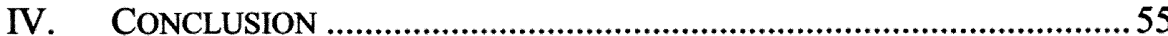

\section{ABSTRACT}

This Article examines Federal facilitators and barriers to stocking healthier options in the food environment, with particular emphasize on how healthy foods do (or more often don't) get to smaller grocery stores or "corner stores" in predominantly low-income areas. As this Article makes clear, public policy is inextricably woven into the fabric of our food systems because of its vital role in providing a variety of healthy food options and promoting equal access to healthy foods in all communities across the United States. Our article provides brief explanations of past, present, and potential examples, including policies ranging from the Commerce Clause to the U.S. Farm Bill to the Clayton Antitrust Act. We focused on laws directly and indirectly facilitating or impeding a healthy food environment from production to promotion. This Article concludes by suggesting the Federal government should work with Tribal, State, and local governments, along with other corporate and community stakeholders to maximize legal and policy strategies to improve access to healthy foods within all U.S. communities.

\section{INTRODUCTION}

The food environment is a causal factor in the current obesity epidemic, particularly in resource scarce areas. ${ }^{1}$ Broadly defined, the food and nutrition environment includes all potential determinants of what individuals eat except for individual-level "factors, such as cognitions, attitudes, beliefs, and skills." At a more local level, the food environment describes food stores (e.g., corner stores, grocery stores, supermarkets, specialty food stores, farmer's markets, and food pantries), restaurants (e.g., fast food and full-service), schools (e.g., cafeterias, vending machines, and snack shops in childcare settings, schools, and colleges), and worksites (e.g., cafeterias,

1. Robin A. McKinnon, et al., Measures of the Food Environment: A Compilation of the Literature, 1990-2007, 36 AM. J. PREVENTIVE. MED. S124 (2009).

2. Karen Glanz, Measuring Food Environments: A Historical Perspective, 36 AM. J. Preventive Med. S93, S93 (2009); See also Karen Glanz, et al., Healthy Nutrition Environments: Concepts and Measures, 19 AM. J. HeALTH Promot. 330, 331 (2005) (setting forth a conceptual model for the study of nutrition environments based on an ecological model of behavior that incorporates constructs found or hypothesized to be related to the healthy eating outcomes). 
vending machines, and snack shops). ${ }^{3}$ Others extend the description of the local food environment beyond the identification and categorization of food outlets to indicators of the availability, accessibility, and affordability of healthy foods, such as the variety of fruits and vegetables, and the exposure to calorie dense foods. ${ }^{4}$

Over the past decade, evidence has increasingly linked the food environment to diet quality. ${ }^{5}$ One of the first food environment studies was the Atherosclerosis Risk in Communities study, with 10,623 socioeconomically, racially, and geographically diverse participants. In this study, African Americans' fruit and vegetable intake increased by thirty-two percent for each additional supermarket in the census tract while Caucasians' fruit and vegetable intake increased by eleven percent with the presence of one or more supermarkets. ${ }^{6}$ Another early study investigated the association between distance to the closest supermarket and quality of diet in 918 pregnant women. ${ }^{7}$ Results showed women living greater than four miles from a supermarket were more than twice as likely to have low dietary quality compared to women living within two miles of a supermarket. ${ }^{8}$ Similar findings were reported by two studies examining the associations within urban populations. ${ }^{9}$ While rural settings are less studied ${ }^{10}$, one investigation focused on a six-county, rural region in Texas found neighborhoods were at least $17.7 \mathrm{~km}$ from the nearest supermarket, a distance challenging rural residents without public transportation or reliable vehicle access. ${ }^{11}$

The associations between the food environment and diet quality can be

3. McKinnon, et al., supra note 1, at S124-S125.

4. Kylie Ball, Anna Timperio \& David Crawford, Neighborhood Socioeconomic Inequalities in Food Access and Affordability, 15 HEALTH \& PlACE 578, 578-579 (2009).

5. Kimberly B. Morland \& Kelly R. Evenson, Obesity Prevalence and the Local Food Environment, 15 Health \& Place 491, 491 (2009).

6. Kimberly B. Morland, et al., The Contextual Effect of the Local Food Environment on Residents' Diets: The Atherosclerosis Risk in Communities Study, 92 AM. J. PUB. HEALTH 1761, 1761-1767 (2002).

7. Barbara A. Laraia, et al., Proximity of Supermarkets is Positively Associated with Diet Quality Index for Pregnancy, 39 J. PREventive MED. 869, 869-75 (2004).

8. Id. at $872-73$

9. Shannon N. Zenk, et al., Neighborhood Retail Food Environment and Fruit and Vegetable Intake in a Multiethnic Urban Population, 23 AM. J. HEALTH. Promot. 255, 25564 (2009) (examining the relationship between the neighborhood food environment and fruit and vegetable intake in 919 multiethnic urban adults and finding the presence of a large grocery store in the neighborhood was associated with 0.69 more daily fruit and vegetable servings); See also Shannon N. Zenk, et al., Fruit and Vegetable Intake in African Americans: Income and Store Characteristics, 29 AM. J. PREVENTIVE MED. 1, 1-9 (2005).

10. See Joseph R. Sharkey, Measuring Potential Access to Food Stores and FoodService Places in Rural Areas in the U.S., 36 AM. J. PREVENTIVE MED. S151, S151-55 (2009) (explaining how most of the food environment work focuses on predominantly urban areas instead of rural areas, where the burden of diet-related chronic disease is high).

11. Joseph R. Sharkey \& Scott Horel, Neighborhood Socioeconomic Deprivation and Minority Composition are Associated with Better Potential Spatial Access to the GroundTruthed Food Environment in a Large Rural Area, 138 J. NUTRITION 620, 620-627 (2008). 
traced down to the shelf level. ${ }^{12}$ To illustrate, a cross-sectional study of 759 Baltimore-area participants directly examined the availability of healthy foods in all food stores within each participant's census tract, specifically within one mile of their residence, and each participant's closest food store. ${ }^{13}$ Based on these examinations, African American participants were more likely to live in neighborhoods with lower availability to healthy foods than the Caucasian participants. ${ }^{14}$ Participants living in areas with low availability reported consuming lower-quality diets. ${ }^{15}$ In school settings, research similarly demonstrates a healthier food environment leads to healthier dietary patterns among children and adolescents. ${ }^{16}$

Studies have also examined the associations between the food environment and health outcomes. ${ }^{17}$ For example, access to healthier food outlets is associated with lower Body Mass Index ("BMI") and lower prevalence of obesity. ${ }^{18}$ On the other hand, increased access to convenience

12. See Elizabeth A. Baker, et al., The Role of Race and Poverty in Access to Foods that Enable Individuals to Adhere to Dietary Guidelines, 3 PREVENTIVE CHRONIC DIS. 1, 111 (2006) (conducting audits of St. Louis, Missouri supermarkets and fast food restaurants to examine the location and availability of food choices that enable individuals to meet the U.S. Dietary Guidelines and finding mixed-race or Caucasian high-poverty areas and all African American areas (regardless of income) were less likely than predominantly Caucasian neighborhoods to have access to foods that enable individuals to meet the recommended dietary guidelines); and Allen Cheadle, et al., Community-Level Comparisons between Grocery Store Environment and Individual Dietary Practices, 20 PREVENTIVE MED. 250, 250261 (1991) (reporting the availability of low-fat and high-fiber products in stores is associated with the reported healthfulness of individual diets; likewise, the health-education material provided by the stores was also associated with the healthfulness of individual diets).

13. Manuel Franco, et al., Availability of Healthy Foods and Dietary Patterns: The Multi-Ethnic Study of Atherosclerosis, 89 AM. J. CLINICAL NUTRITION 897, 897-904 (2009).

14. Id. at 899 .

15. Id.

16. See Simone A. French \& Gloria Stables, Environmental Interventions to Promote Vegetable and Fruit Consumption Among Youth in School Settings, 37 PREventIVE MED. 593, 593-610 (2003) (concluding that environmental change interventions in schools may increase fruit and vegetable consumptions among children and adolescents based on a review of the school food environment literature); and Dianne Neumark-Sztainer, et al., School Lunch and Snacking Patterns Among High School Students: Associations with School Food Environment and Policies, 2 InT'L. J. BeHAV. NuTRITION \& PHYSICAL ACTIVITY 1, 1-7 (2005) (finding student snack purchases at school were significantly associated with the number of snack machines at schools).

17. Morland \& Evenson, supra 5, at 491.

18. See Steven Cummins \& Sally Macintyre, Food Environments and ObesityNeighbourhood or Nation?, 35 INT'L. J. EPIDEMOLOGY 100, 100-104 (2006) (reviewing the evidence for the influence of food outlets, discussing if where you lives makes you fat, and concluding that the observational evidence in the U.S. tends to support the notion that the local food environment influences healthy eating and weight status, but these associations do not appear to be as strong in international settings); Morland \& Evenson, supra note 5, at 491-495 (investigating the presence of food establishments and obesity among 1295 adults living in the southern region of the U.S. and finding lower prevalence of obesity in areas with more supermarkets and higher obesity prevalence in areas with more small grocery stores or fast food restaurants); andAndrew Rundle, et al., Neighborhood Food Environment and Walkability Predict Obesity in New York City, 117 ENVTL. HEALTH PERSPECT. 442, 442- 
stores or smaller grocery stores, which tend to stock less fruits and vegetables and more processed foods, is associated with higher obesity prevalence. ${ }^{19}$ Increased access to fast food restaurants has also been associated with increased obesity prevalence ${ }^{20}$; some studies, however, have found slight to no associations. ${ }^{21}$

447 (2009) (examining the association of neighborhood food environment in New York City with BMI and obesity and reporting that the density of healthy food stores (e.g., supermarkets, fruit and vegetable markets, and natural food stores) was inversely associated with BMI and lower prevalence of obesity).

19. Morland \& Evenson, supra 5, at 491-95; See also Irina B. Grafova, Overweight Children: Assessing the Contribution of the Built Environment 47 PREVENTIVE MED. 304, 304-08 (living in a neighborhood with higher convenience store density is associated with a higher probability of being overweight, based on analyses with 2482 children aged 5-18).

20. Morland \& Evenson, supra note 5, at 491-95; and Grafova, supra note 19, at 30408; See also Shin-Yi Chou, et al., An Economic Analysis of Adult Obesity: Results From the Behavioral Risk Factor Surveillance System, 23 J. HEALTH ECON. 565, 565-87 (2004) (employing the 1984-1999 Behavioral Risk Factor Surveillance System, augmented with State level measures pertaining to the per capita number of fast food and full-service restaurants and reporting large positive effects associated with the per capita number of restaurants); Janet Currie, et al., The Effect of Fast Food Restaurants on Obesity, NBER WORKING PAPER SERIES No. 14721 (2009), available at http://www.nber.org/papers/ w14721 (last visited May 15, 2010) (investigating the supply of fast food on three million school children and over one million pregnant women and finding that among ninth grade children, a fast food restaurant within a tenth of a mile of a school is associated with at least a five percent increase in obesity and among pregnant women, a fast food restaurant within a half mile of her residence results in about a two percent increase in the probability of gaining over twenty kilos); Fuzhong Li, et al., Built Environment, Adiposity, and Physical Activity in Adults Aged 50-75, 35 AM. J. Preventrve MED. 38, 38-46 (2008) (finding as the density of fast food outlets increased so did resident-levels of overweight/obesity rates in a cross-sectional sample in Portland, OR); Jay Maddock, The Relationship Between Obesity and the Prevalence of Fast Food Restaurants: State-Level Analysis, 19 AM. J. Health Promot. 137, 137-43 (2004) (accounting for six percentage of variance in State obesity rates with square miles per fast food restaurants); Neil K. Mehta \& Virginia W. Chang, Weight Status and Restaurant Availability: A Multi-Level Analysis, 34 AM. J. PREvenTrve MED. 127, 127-33 (2008) (analyzing the relationship between the restaurant environment and weight status across counties in the U.S. and reporting that fast food restaurant density and a higher ratio of fast food to full-service restaurants were associated with higher individual-level weight status while a higher density of full-service restaurants was associated with lower weight status); and May C. Wang, et al., Changes in Neighborhood Food Store Environment Food Behavior and Body Mass Index, 1981-1990, 11 PUB. HEALTH NuTRITION 963, 963-70 (2007) (increasing number and density of fast food restaurants in four mid-sized cities in agricultural regions of California during 1981-1990; likewise, the obesity prevalence in these communities increased during this period).

21. See Hillary L. Burdette \& Robert C. Whitaker, Neighborhood Playgrounds, Fast Food Restaurants, and Crime: Relationships to Overweight in Low-Income Preschool Children, 38 PREVENTIVE MED. 57, 57-63 (2004) (reporting no association between 7,020 low-income children from Cincinnati, $\mathrm{OH}$ overweight status and their proximity to fast food restaurants); David A. Crawford, et al., Neighborhood Fast Food Outlets and Obesity in Children and Adults: The CLAN Study, 3 INT'L. J. PeDIATRIC OBESITY 249, 249-56 (2008) (providing little support for the relationship between fast food outlets and increased obesity in an Australian elementary school children); Robert W. Jeffery, et al., Are Fast Food Restaurants an Environmental Risk Factor for Obesity?, 3 INT'L. J. BEHAV. NUTRITION \& Physical ACTIVITY 2, 2-7 (2006) (using a telephone survey of 1033 Minnesota residents to determine that proximity to fast food restaurants to home or work was not associated with eating at fast food restaurants nor with BMI); Russ P. Lopez, Neighborhood Risk Factors for 
Lower socioeconomic populations are more at risk for living in unhealthy food environments. ${ }^{22}$ That is, supermarkets and gas stations with convenience stores are more prevalent in wealthier neighborhoods than the poorest neighborhoods in a diverse four-State sample. ${ }^{23}$ Fasts food restaurants are also more prevalent in low-income neighborhoods. ${ }^{24}$ Racial disparities also exist. African American neighborhoods in Detroit were over one mile further from the nearest supermarkets than were Caucasian neighborhoods. ${ }^{25}$ Studies have also found African American neighborhoods had more fast food restaurants than Caucasian neighborhoods. ${ }^{26}$ In a predominantly low-income, urban Latino community, a survey of 251 grocery stores ("bodegas") and 25 supermarkets found low-fat milk available in 73 percent of bodegas and 96 percent of supermarkets; nonetheless, low-fat milk only accounted for 15 percent of total milk volume in bodegas and 37

Obesity, 15 OBESITY 2111, 2111-19 (2007) (combining data from the U.S. Behavioral Risk Factor Surveillance System with data from the U.S. Census and reporting that fast food establishment density was poorly associated with obesity risk); and Roland Sturm \& Ashlesha Datar, Body Mass Index in Elementary School Children, Metropolitan Area Food Prices and Food Outlet Density, 119 PUB. HEalth 1059, 1059-68 (2005) (reporting no significant affects on BMI changes during a four-year period in a nationally representative sample of kindergarten children in relationship to food outlet density.

22. Kimberly Morland, et al., Neighborhood Characteristics Associated with the Location of Food Stores and Food Service Places, 22 AM. J. PreVENTIVE MED. 23, 23-29 (2002).

23. Id. at 26-27.

24. See Baker, et al., supra note 12, at 1-11; Jason P. Block, et al., Fast Food, Race/Ethnicity, and Income: A Geographic Analysis, 27 AM. J. PREVENTIVE MED. 211, 21117 (2004) (finding in New Orleans, LA that fast food restaurant density in shopping areas with one-mile buffers was independently correlated with median household income and that predominantly black neighborhoods have 2.4 fast food restaurants per square mile compared to 1.5 restaurants in predominantly white neighborhoods); Lisa M. Powell, et al., The Availability of Fast-Food and Full-Service Restaurants in the United States: Associations with Neighborhood Characteristics, 33 AM. J. PReventive MED. S240, S240-45 (2007) (examining associations between local-area racial, ethnic, and income characteristics and the availability of full-service and fast-food restaurants and finding moderately higher proportions of fast-food among total restaurants in only urban areas, near-low, middle-, and near-high versus high-income neighborhoods and predominantly black versus white neighborhoods); Paul A. Simon, et al., Proximity to Fast Food Restaurants to Schools: Do Neighborhood Income and Type of School Matter?, 47 PREVENTIVE MED. 284, 284-88 (2008) (noting fast food restaurant proximity is inversely related to neighborhood income for schools in the highest commercial areas); and Shannon N. Zenk \& Lisa M. Powell, US Secondary Schools and Food Outlets, 14 Health \& Place 336, 336-46 (2008) (finding schools in the lowestincome versus the highest-income neighborhoods have more fast food restaurants and convenience stores).

25. Shannon N. Zenk, et al., Neighborhood Racial Composition, Neighborhood Poverty, and the Spatial Accessibility of Supermarkets in Metropolitan Detroit, 95 AM. J. PUB. HEALTH 660, 660-67 (2005).

26. See Baker, et al., supra note 12, at 1-11; Block, et al., supra note 24, at 211-217; Maida P. Galvez, et al., Race and Food Store Availability in an Inner-City Neighbourhood, 11 PUB. HEALTH NUTRITION 623, 624-31 (2007) (examining food store availability in East Harlem, New York and finding that African American census blocks had neither supermarkets nor grocery stores); and Naa Oyo A. Kwate, et al., Inequality in Obesigenic Environments: Fast Food Density in New York City, 15 Health \& Place 364, 364-73 (2009) (finding predominantly Black areas had higher densities of fast food than predominantly White areas in New York City). 
percent of total milk volume in supermarkets. ${ }^{27}$ Another study determined Hispanic youth attending U.S. public secondary schools were more likely to attend schools surrounded by convenience stores, restaurants, snack stores, or off-licenses than other race/ethnic groups. ${ }^{28}$ Even though American Indians have disproportionate childhood obesity and type 2 diabetes rates, ${ }^{29}$ no studies (to our knowledge) have assessed the food environment in American Indian settings. ${ }^{30}$ Insight into American Indian access to healthy food is limited to the White Mountain, San Carlos Apache, and Navajo Nation, which have recently initiated healthy store interventions. ${ }^{31}$ In order to access a diverse supply of healthy foods, some of these American Indian community members traveled as far as thirty to forty minutes off the reservation. $^{32}$

In spite of the growing evidence-base, work remains on developing

27. Howell Wechsler, et al., The Availability of Low-Fat Milk in an Inner-City Latino Community: Implications for Nutrition Education, 85 AM. J. PUB. HEALTH 1690, 1690-92 (1995); see also Joseph R. Sharkey, et al., Association Between Neighborhood Need and Spatial Access to Food Stores and Fast Food Restaurants in Neighborhoods of Colonias, 8 INT'L. J. HEALTH GEOGRAPHICS 9, 9-25 (2009) (finding in a predominantly Hispanic/Latino population living in Hidalgo County in the Lower Rio Grande Valley of Texas that residents in neighborhoods with increased deprivation had to travel a significantly greater distance to the nearest supercenter or supermarket, grocery store, mass merchandiser, dollar store, and pharmacy for food items); and Roland Sturm, Disparities in the Food Environment Surrounding US Middle and High Schools, 122 PUB. HEALTH 681, 681-90 (2008) [hereinafter Sturm, Disparities].

28. Sturm, Disparities, supra note 27, at 681-690.

29. See Sarah E. Anderson \& Robert C. Whitaker, Prevalence of Obesity Among US Preschool Children in Different Racial and Ethnic Groups, 163 Archives PEDIATRICS ADOLESCENT MED. 344, 344-48 (2009) (reporting that American Indian four-year-old preschoolers endured a childhood obesity prevalence rate that doubled the non-Hispanic white and Asian rates and were notably higher than Hispanic and non-Hispanic black children rates); Dana Dabelea, et al., Diabetes in Navajo Youth: Prevalence, Incidence, and Clinical Characteristics: The SEARCH for Diabetes in Youth Study, 32 DiabeTES CARE S141, S14147 (2009) (describing how type 2 diabetes is now a common disease among American Indian children over the age of ten); and David S. Jones, The Persistence of American Indian Health Disparities, 96 AM. J. PUB. HEALTH 2122, 2122-34 (2006) (discussing how American Indians have endured health disparities since the first contact with European explorers over five hundred years ago, and these disparities persistence from infancy through adulthood and across a broad spectrum of diseases).

30. Joel Gittelsohn \& Sangita Sharma, Physical, Consumer, and Social Aspects of Measuring the Food Environment Among Diverse Low-Income Populations, 36 AM. J. PREVENTIVE MED. S161, S161 (2009).

31. See Sarah Curran, et al., Process Evaluation of a Store-Based Environmental Obesity Intervention on Two American Indian Reservations, 20 HEALTH EDUC. RES. 719, 71929 (2005); Joel Gittelsohn, et al., Psychosocial Determinants of Food Purchasing and Preparation in American Indian Households, 38 J. NUTRITION EDUC. BEHAV.163, 163-68 (2006); Amy E. Vastine, et al., Formative Research and Stakeholder Participation in Intervention Development, 29 AM. J. Health BeHav. 57, 57-69 (2005); and Marla Pardila, International Health, Center for Human Nutrition, Johns Hopkins University, et al.; Presentation at the 136th American Public Health Association Annual Meeting: Using Community Workshops to Develop a Culturally Tailored Obesity and Diabetes Intervention Program for the Navajo Nation (Oct. 28, 2008).

32. Vastine, et al., supra note 31 , at 57-69. 
more valid and reliable measures, as well as strengthening the connection between food environment research and policy implications. ${ }^{33}$ This Article aims to address the relevant policy implications of the food environment evidence-base by focusing on the Federal facilitators and barriers to stocking healthier options in the food environment. Our emphasis is on how healthy foods do (or more often do not) get to smaller grocery stores or "corner stores" in predominantly low-income areas. As this Article makes clear, public policy is inextricably woven into the fabric of our food systems because of its vital role in providing a variety of healthy food options and promoting equal access to healthy foods in all communities across the United States. Our Article provides brief explanations of past, present, and potential fiscal facets of Federal food authority (Part I). We then focus on laws directly and indirectly facilitating or impeding a healthy food environment from production to promotion (Part II). This Article provides recommendations for future Federal action and concludes (Part III) by suggesting the Federal government should work with Tribal, State, and local governments, along with other corporate and community stakeholders to maximize legal and policy strategies to improve access to healthy foods within all U.S. communities.

\section{FISCAL FACETS OF FEDERAL FOOD AUTHORITY}

The Federal government has significantly influenced the food environment from our initial agricultural society to today's modern global food supply. $^{34}$ This section focuses on the past, present, and potential of the Commerce Clause and the Taxing and Spending Power.

33. See Leslie A. Lytle, Measuring the Food Environment: State of the Science, 36 AM. J. Preventive Med. S134, S134-44 (2009); Brian E. Saelens \& Karen Glanz, Work Group I: Measures of the Food and Physical Activity Environment: Instruments, 36 AM. J. Preventive MEd S166, S166-70 (2009); Stephen A. Matthews, et al., Work Group II: Using Geographic Information Systems for Enhancing Research Relevant to Policy on Diet, Physical Activity, and Weight, 36 AM. J. PREVENTIVE MED S171, S171-76 (2009); J. Michael Oakes, et al., Work Group III: Methodologic Issues in Research on the Food and Physical Activity Enviroments: Addressing Data Complexity, 36 AM. J. PREVENTIVE MED S177, S177-81 (2009); Mary Story, et al., Work Group IV: Future Directions for Measures of the Food and Physical Activity Environments, 36 AM. J. PREVENTIVE MED S182, S182-88 (2009); Angela M. Odoms-Young, et al., Measuring Food Availability and Access in African-American Communities, 36 AM. J. PREVEnTIVE MED. S145, S145-50 (2009); Gittelsohn \& Sharma, supra note 30, at S161-65; and Joanna E Holsten, Obesity and the Community Food Environment: A Systematic Review, 12 PUB. HeAlth NuTRITION 397, 397-405 (2008).

34. Lawrence O. Gostin, et al., Assessing Laws and Legal Authorities for Obesity Prevention and Control, J. LAW MED. \& ETH. 28-36 (2009) (putting forth examples of how current laws and legal authorities affect obesity prevention and control in both positive and negative ways). 


\section{A. Commerce Clause}

The Constitution enumerates powers to the Federal government, providing the general authority to regulate virtually all economic activities in the nation, including the food environment. ${ }^{35}$ One of the most important powers is conferred through the Commerce Clause, which states: "Congress shall have the power ...[t]o regulate Commerce with foreign Nations, among the several States, and with the Indian Tribes."36 A historical understanding of the Commerce Clause illustrates its long-time connection with agricultural activities, public health, and food safety.

\section{History of the Commerce Clause}

To begin, the Commerce Clause was added to the Constitution to enable our nation to regulate foreign commerce and to prohibit States from imposing burdens on each other. ${ }^{37}$ The Supreme Court initially defined Congress' commerce power in 1824 while considering a monopoly granted to a steamboat inventor to exclusively operate his boats on the Hudson River between New York and New Jersey. ${ }^{38}$ Interpreting the language of the Commerce Clause with the Necessary and Proper Clause ${ }^{39}$, Justice Marshall broadly determined that commerce "describes the commercial intercourse between nations, and parts of nations, in all its branches, and is regulated by prescribing rules for carrying on that intercourse." ${ }^{, 40}$ Justice Marshall also held Congress had the "utmost" power "to prescribe the rule by which commerce is to be governed." 41 The "sole restraints" on Congress were political. $^{42}$

The Court narrowed its view of the Commerce Clause during the Industrial Revolution to leave regulatory matters to the State governments. ${ }^{43}$ First, the Court narrowly defined commerce in United States v. E.C. Knight Co., ${ }^{44}$ the first significant case brought under the Sherman Anti-Trust Act dealing with a monopoly over the manufacturing of refined sugar. In this case, the Court construed commerce as an event which "succeeds to manufacture, and is not a part of it."

35. See, id. at 30 .

36. U.S. CONST. art. $1, \S 8$, cl. 3.

37. THE FEDERALIST No. 42, at 267-68 (James Madison) (Clinton Rossiter ed. 1961).

38. Gibbons v. Ogden, 22 U.S. 1 (1824).

39. U.S. CONST. art. $1, \S 8, \mathrm{cl} .18$.

40. Gibbons v. Ogden, 22 U.S. at 189-90.

41. Id. at 196.

42. Id. at 197.

43. ERWIN CHERMERINSKY, CONSTITUTIONAL LAW 116-120 (Aspen Law \& Business 2d ed.2005).

44. 156 U.S. 1 (1895).

45. E.C. Knight, 156 U.S. at 12; See also United States v. Butler, 297 U.S. 1 (1936); 
time to limit Federal commerce power was to take varying approaches to what constituted commerce "among the States."46 One agricultural example during this period is Swift \& Co. v. United States. ${ }^{47}$ In this case, Justice Holmes considered a government action under the Sherman Act alleging price fixing by meat dealers. The dealers argued their business activities were local and beyond Congress' power. ${ }^{48}$ Justice Holmes cultivated the stream of commerce doctrine to hold:

When cattle are sent for sale from a place in one state, with the exception that they will end their transit, after purchase, in another, and when in effect they do so, with only the interruption necessary to find a purchaser at the stock yards, and when this is a typical, constantly recurring course, the current thus existing is a current of commerce among the states, and the purchase of the cattle is a part and incident of such commerce. $^{49}$

This doctrine was used to limit business with a public interest and essentially only applied to cases dealing with stockyards and grain exchanges. ${ }^{50}$ During that era, however, this doctrine was not applied to the poultry business. $^{51}$

The third and final approach the Court used during the Industrial Revolution to limit Federal commerce authority was the Tenth Amendment. ${ }^{52}$ This Amendment states: "The powers not delegated to the United States by the Constitution, nor prohibited by it to the States are reserved to the States respectively, or to the people." ${ }^{, 53}$ During this era, the Court protected States' rights and determined that the Tenth Amendment reserved a zone of activities for exclusive State control. ${ }^{54}$ Earlier however, the Court dis-

Carter v. Carter Coal Co., 298 U.S. 238 (1936); Champlin Refining Co. v. Corporation Comm'n, 286 U.S. 210 (1932); Utah Power \& Light Co. v. Pfost, 286 U.S. 165 (1932); Oliver Iron Co. v. Lord, 262 U.S. 172; and. Coe v. Town of Errol, 116 U.S. 517 (1886).

46. CHERMERINSKY, supra note 43, at 120-24.

47. 196 U.S. 375 (1905).

48. Swift \& Co., 196 U.S. at 398-399.

49. Id.

50. See Barry Cushman, Continuity and Change in Commerce Clause Jurisprudence, 55 ARK. L. REV. 1009, 1023 (2003).

51. A.L.A. Schechter Poultry Corp. v. United States, 295 U.S. 495 (1935) (holding Congress could only regulate matters with a "direct effect" on interstate commerce and, therefore, exceeded its power when attempting to regulate a slaughterhouse engaged in distribution, not commerce).

52. CHERMERINSKY, supra note 43, at 125-29.

53. U.S. CONST. amend. X.

54. CHERMERINSKY, supra note 43, at 125; See also Hammer v. Dagenhart, 247 U.S. 251 (1918) (holding that the Federal government's attempt to regulate production by prohibiting transportation in interstate commerce of manufactured goods from a factory employing children violated State's rights under the Tenth Amendment and was unconstitution- 
missed a Tenth Amendment challenge to the Federal regulation of interstate shipments of lottery tickets. ${ }^{55}$ Similar prohibition laws were upheld during this time, often dealing with diseased or dangerous commodities. ${ }^{56}$ Taken together, these three steps striped Congress of significant authority to regulate key sectors of this young nation's economy, including agriculture, manufacturing, and mining.

The Great Depression began a new era of the Court's interpretation of the Commerce Clause. To illustrate, in NLRB v. Jones \& Laughlin Steel Corp. ${ }^{57}$ Justice Hughes disregarded the prior "direct effects" approach and considered if the economic activities of the National Labor Relations Act of 1935 were "close and substantial" to commerce. ${ }^{58}$ The majority of the Court found production to be subject to the Commerce Clause. ${ }^{59}$ Rather than applying formal rules, this decision suggested the Court review commerce cases on a case-by-case basis. ${ }^{60}$ Other key decisions overruled the earlier restrictive Commerce Clause approaches and helped expand Congress' power to regulate commerce. ${ }^{61}$

Congress' power to regulate commerce was broadly construed by the Court from 1937 until 1992. ${ }^{62}$ During this period, the Court upheld civil rights laws, ${ }^{63}$ regulatory laws, ${ }^{64}$ and criminal laws ${ }^{65}$ despite challenges that

al).

55. Champion v. Ames, 188 U.S. 321 (1903) (finding a difference between regulation and prohibition, the Court upheld a Federal law prohibiting the interstate transportation of lottery tickets).

56. See, e.g., Oregon-Wash. R.R. \& Nav. Co. v. Washington, 270 U.S. 87 (1926); Clark Distilling Co. v. Western Md. Ry. Co., 242 U.S. 311 (1917); Hipolite Egg Co. v. United States, 220 U.S. 45 (1911); and. Reid v. Colarado, 187 U.S. 137 (1902).

57. 301 U.S. 1 (1937).

58. Id. at 37 .

59. Id.

60. Id. at 37-38.

61. See Wickard v. Filburn, 317 U.S. 111 (1942) (determining Congress had the authority to regulate even one farmer's overproduction of wheat if the cumulative effects of this activity "might reasonably be deemed nationally significant" and exert " a substantial economic effect on interstate commerce"); United States v. Wrightwood Dairy Co., 315 U.S. 110 (1942) (permitting the Federal regulation of the price of milk produced and sold intrastate, because the price of milk in State would affect the price of, and the commerce in, interstate milk); and. United States v. Darby, 312 U.S. 100 (194 finding that Congress had the authority to regulate the shipment in interstate commerce of lumber manufactured by employees who either worked too much or were not paid enough, since this productive activity had a substantial effect on commerce).

62. CHERMERINSKY, supra note 43, at 138.

63. See Heart of Atlanta Motel, Inc. v. United States, 379 U.S. 241 (1964) (allowing Congress to use its power vested under the Commerce Clause to prohibit a motel business from discriminating against African Americans); and Katzenbach v. McClung, Sr. and McClung, Jr., 379 U.S. 294 (1964) (finding the Commerce Clause provides Congress authority to prohibit discriminatory activities of retail establishments, including restaurants that imported a significant portion of their food from other States, and noting the power of Congress in commerce is "broad and sweeping").

64. See Hodel v. Indiana, 452 U.S. 314 (1981) (finding that a law is only unconstitutional under the Commerce Clause if "there is no rational basis for a congressional finding that the regulated activity affects interstate commerce, or that there is no reasonable connec- 
the law was unconstitutional under the Commerce Clause. New limits, however, began to emerge in United States v. Lopez. ${ }^{66}$ In Lopez, the Court considered the constitutionality of the Gun-Free School Zones Act of 1990, which made it a Federal offense "for any individual knowingly to possess a firearm at a place that the individual knows, or has reasonable cause to believe, is a school zone." came to school one day carrying a concealed .38 caliber hand-gun and five bullets. $^{68}$. The student was convicted of violating the Gun-Free School Zones Act. ${ }^{69}$ The Court reversed this conviction, concluding that the Act was a criminal statue and did not regulate economic or commercial activity. ${ }^{70}$ Another law struck down as unconstitutional, in spite of overwhelming support at the State and local levels, was the Violence Against Women Act of 1994. ${ }^{71}$ The Court based its decision on three of the four Lopez factors: (1) the law's attempt to address violence against women was not an "economic activity"; (2) the law had no "jurisdictional element" with an express connection to or effect on commerce; (3) while the Congressional findings regarding this Act satisfy the third factor of Lopez, these findings failed to demonstrate the "substantial effect" between violence against women and commerce. ${ }^{72}$ These two cases narrowed the scope of the commerce power and demonstrated the Court's increased scrutiny of Congressional attempts to regulate commerce.

\section{Commerce Clause Current Food Environment Possibilities}

Using the past to guide today's possibilities, Congress seems to still have the power to regulate even a small amount of wheat used for one household. ${ }^{73}$ Modern trends have opened the door to uncertainty in Congress' commerce power while still leaving opportunities for Congress to use the Commerce Clause to remedy social injustices, such as racial discrimination in placement of food outlets (or lack thereof) ${ }^{74}$ Specifically, the Civil Rights Act of 1964 (Title II) entitled all persons to equal access to any public accommodation, including inns, hotel, motels, restaurants, and cafete-

tion between the regulatory means selected and the asserted ends." Id. at 323-24).

65. Perez v. United States, 402 U.S. 146 (1971) (permitting Congress to make a local "loan shark" a criminal for threatening violence to collect money borrowed to a butcher by showing, amongst other congressional findings, that loan sharking was "the second largest source of revenue for organized crime").

66. 514 U.S. 549 (1995).

67. Id. (quoting 18 U.S.C. $\$ 922(q)(1)(a)$ (1990), invalidated by United States v. Lopez, 514 U.S. $549(1995))$.

68. Id. at 551 .

69. Id. at 552 .

70. Id. at 568 .

71. United States v. Morrison, 529 U.S. 598 (2000).

72. Id. at 602-603.

73. Wickard, 317 U.S. at 111.

74. Heart of Atlanta Motel, Inc., 379 U.S. at 241; and Katzenbach, 379 U.S. at 294. 
rias, without racial or religious discrimination if their "operations affect commerce."75 Later, the Fair Housing Law of 1968 was added to prohibit discrimination in the sale, rental, and financing of dwelling and in other housing-related transactions, based on color, national origin, religion, sex, familial status, and disability. ${ }^{76}$ Congress' authority to address social inequalities through its commerce power has not been extended to regulate the placement of food stores or restaurants. ${ }^{77}$ Additional authority to address inequalities in the food environment may be provided to the Federal government in the Civil Rights Amendments; nevertheless, the Courts have defined these powers very narrowly and may require State action. ${ }^{78}$

The Tenth Amendment may limit Federal actions attempting to address public health issues if deemed to be issues of "traditional state concern." 79 No Child Left Behind illustrates that even education, a traditional State issue, has been increasingly subjected to Federal mandates. ${ }^{80}$ While the framers of the Constitution did not intend for the Federal government to directly address health, the Federal government has the authority to provide for the general welfare and regulate commerce. ${ }^{81}$ Initially, the Federal government dealt with communicable diseases through importation oversight. ${ }^{82}$ Then, increasingly through its power to generate revenue, which will be discussed further in Section B, the Federal government supported the health efforts of the State and local governments. ${ }^{83}$ Today, the Federal government is a major purchaser of health care through Medicare and partners with States to provide health care to the poor through Medicaid. ${ }^{84}$ Established in 1946, the U.S. Health and Human Services ("HHS") Centers for Disease Prevention and Control ("CDC") has become our nation's principal health agency. ${ }^{85}$ The CDC cannot issue any mandates or dictate law. ${ }^{86}$ Nonetheless, the CDC's recommendations influence State public health policy, encourage critical State uniformity on key issues, and facilitate cost-

75. Civil Rights Act of 1964, Pub. L. No. 88-352, 78 Stat. 241 (1964).

76. Fair Housing Act, 42 U.S.C. $\$ 3601$ (1968).

77. Morland et al., supra note 22, at 28.

78. U.S. CONST. amend. XIII, XIV, and XV; see also Morrison, 529 U.S. at 598; Georgia v. McCullom, 505 U.S. 42, 50 (1992); Moose Lodge No. 107 v. Irvis, 407 U.S. 163, 179 (1972); United States v. Guest, 383 U.S. 745 (1966); Burton v. Wilmington Parking Authority, 365 U.S. 715 (1961); United States v. Harris, 106 U.S. 629 (1883); and Civil Rights Cases, 109 U.S. 3 (1883).

79. Lopez, 514 U.S. at $580,583$.

80. No Child Left Behind Act of 2001, Pub. L. No.107-110, 115 Stat. 1425 (2001).

81. BERNARD J. TURNOCK, ESSENTIALS OF PUBLIC HEALTH 74 (Jones and Bartlett Publishers 2007).

82. Id.

83. Hospital Survey and Construction Act (Burton-Hill Hospital Survey \& Construction Act, or Hill-Burton Act), Pub. L. No. 79-725, 60 Stat. 1040 (1946).

84. Social Security Amendments of 1965, Pub. L. No. 89-97, 79 Stat. 286 (1965).

85. Centers for Disease Control and Prevention, Our History - Our Story, http:// www.cdc.gov/abouthistory/ourstory.htm (last visited June 9, 2009).

86. U.S. CONST. amend. X. 
effective and efficient State flexibility. ${ }^{87}$

Of equal importance, the Federal government through the U.S. Department of Agriculture ("USDA") National School Lunch Program ("NSLP") provides assistance to meal programs administered by States offering low-cost or free lunches to more than thirty million children each school day. ${ }^{88}$ The NSLP was enacted in 1946 "as a measure of national security, to safeguard the health and well-being of the Nation's children and encourage the domestic consumption of nutritious agricultural commodities and other foods." ${ }^{\circ 9}$ Participation in the Federal government's food stamp program, now known as the USDA Supplemental Nutrition Assistance Program ("SNAP"), reached an all-time (non-disaster) high of twenty-nine million people per month in 2008. ${ }^{90}$ Through the USDA Special Supplemental Nutrition for Women, Infants, and Children ("WIC"), the Federal government also provides nutritious foods, nutrition education, and referrals to health and other social services to low-income pregnant, postpartum, and breastfeeding women, along with low-income or nutritionally at-risk infants and children up to age five. ${ }^{91}$ WIC currently serves over nine million people each month. ${ }^{92}$ Collectively, these investments illustrate the Federal government's increasing role and important State partnerships in our nation's food, nutrition, and health issues. Good food, nutrition, and health, individually and collectively, are fundamental to this country's general welfare.

To successfully craft legislation capable of facilitating the production and promotion of healthy foods in the U.S. and addressing inequalities in the local food environment among U.S. communities, Congress should explicitly develop regulatory efforts to deal with the economic and commercial aspects of our food systems. For instance, Congress could establish laws to regulate the conservation of agricultural land. ${ }^{93}$ These attempts to regulate (e.g., requiring minimal standards for the percentage of healthy foods at urban corner stores or small rural stores that are fresh fruits and

87. Centers for Disease Control and Prevention, supra note 85.

88. United States Department of Agriculture Food and Nutrition Service, National School Lunch Program, http:/www.fns.usda.gov/cnd/Lunch/AboutLunch/NSLPFactSheet.pdf (last visited June 9, 2009). (1946).

89. The Richard B. Russell National School Lunch Act of 1946, 42 U.S.C. $\$ 1751$

90. United States Department of Agriculture Food and Nutrition Service, Supplemental Nutrition Assistance Program (SNAP): A Short History of SNAP, http://www.fns.usda.gov/ FSP/rules/Legislation/about.htm (last visited June 9, 2009).

91. United States Department of Agriculture Food and Nutrition Service, Nutrition Program Facts: The Special Supplemental Nutrition Program for Women, Infants, and Children, http://www.fns.usda.gov/wic/WIC-Fact-Sheet.pdf (last visited June 13, 2009).

92. Id.

93. Jamie Harvie, et al., A New Healthcare Prevention Agenda?: Sustainable Food Procurement and Agricultural Policy, 4 J. Hunger \& ENVTL. NuTRITION 409, 419-23 (2009). 
vegetables) or prohibit (e.g., mandating the reduction of pesticide use) should expressly connect the regulatory endeavor to direct agricultural economic activities.

Although possibly construed as an indirect effect, Congress should demonstrate in its Congressional findings the increasingly correlated effects of unhealthy food system processes and inequalities in our food systems on the health of the U.S. population-from senior citizens to infants. One relevant USDA finding suggests the U.S. production of fruits and vegetables is insufficient to supply the amount necessary for every American to meet the Dietary Guidelines for Americans. ${ }^{94}$ Another finding that could be explicitly detailed is U.S. spending on health care, which is estimated at more than two trillion dollars a year. ${ }^{95}$ The amount of Federal funding a State receives has been shown to impact the number of obesity prevention policy initiatives a State implements. ${ }^{96}$ Health also has significant economic impacts on worker productivity: An estimated eighteen million adults were not working in 2003 due to disability, chronic disease, or another health issue. $^{97}$ Congress should proceed cautiously in justifying its actions based on health care costs and lost worker productivity, since these costs may be viewed by a restrictive Court as too indirect to permit a nexus between the regulation and commerce.

\section{Concluding Points on the Commerce Clause}

Hence, the Commerce Clause is the Federal government's most powerful tool to improve access to healthy foods. Congress' commerce power has a solid foundation for facilitating the enactment of laws that address dangerous, diseased, and disparate business processes affecting interstate commerce and have the potential to promote our country's general welfare.

\section{B. Taxing and Spending Power}

The Tax and Spend Clause contains other enumerated powers the Federal government has used to regulate the food environment and can poten-

94. JeAn C. BuZby, et Al., USDA Economic Res. SERV.. Possible IMPliCAtions for U.S. Agriculture From Adoption of SElect Dietary Guidelines (2006), available at http://www.ers.usda.gov/Publications/ERR31/ (last visited June 9, 2009).

95. U.S. Department of Health and Human Services, Agency for HealthCare RESEARCH AND QUALITY, NATIONAL HEALTHCARE QUALITY REPORT 7 (2008), available at http://www.ahrq.gov/qual/nhqr08/nhqr08.pdf (last visited June 9, 2009).

96. James Hersey, et al., The Association between Funding for Statewide Programs and Enactment of Obesity Legislation, 42 J. NUTRITION EDUC. \& BEHAV. 54, 51-56 (2010).

97. Karen Davis, et al., The Commonwealth Fund, Health and Productivity AMONG U.S. WORKERS (2005), available at http:/www.commonwealthfund.org/usr_doc/ 856_Davis_hlt_productivity_USworkers.pdf (last visited June 9, 2009). 
tially apply further. ${ }^{98}$ The Constitution states: "Congress shall have Power To lay and collect Taxes, Duties, Imposts, and Excises, to pay the Debts and provide for the common Defense and general Welfare of the United States; but all Duties, Imposts, and Excises shall be uniform throughout the United States." The tax must provide for a common defense and general welfare; yet this condition is not usually a major hurdle since the Courts give great deference to Congress "unless the choice is clearly wrong, a display of arbitrary power, not an exercise of judgment."100 The term "general welfare" is flexible and can adopt to meet current country needs and circumstances. $^{101}$

\section{The Power to Tax}

Congress has used its tax power for a variety of reasons, including protecting American business interests from foreign competitors. ${ }^{102}$ Unless there is an extreme abuse of power, Congress' motive is generally not a cause for striking down a tax, even if it imposes a steeper tax on margarine colored to resemble butter than on uncolored margarine. ${ }^{103}$ Nonetheless, Congress cannot use its tax power to regulate an activity it could not otherwise regulate. ${ }^{104}$ For example, Congress tried to employ taxes on the profits of employers using child labor after they failed to curtail the issue through the Commerce Clause. ${ }^{105}$ The Court struck down this tax as invalid given the improper motive. ${ }^{106}$ Likewise, the Court did not permit Congress to use taxes to regulate agricultural production - an activity within the reserved powers of the States. ${ }^{107}$ The Court reached this decision based on Congress' inappropriate objectives, not because it was a tax for the general welfare. ${ }^{108}$ Later decisions have followed McCray's deferential approach. ${ }^{109}$ In more recent years, the Court has permitted Congress to use taxes to regulate or suppress undesirable activities outside its direct authority, such as the sale of marijuana ${ }^{110}$ and local gambling ${ }^{111}$. The tax, however, cannot vi-

98. U.S. CONST. art. $1, \S 8, \mathrm{cl} .1$.

99. Id.

100. Helving v. Davis, 301 U.S. 619,640 (1937).

101. Id. at 641 .

102. See J.W. Hampton, Jr. \& Co. v. United States, 276 U.S. 394 (1928).

103. McCray v. United States, 195 U.S. 27 (1904).

104. Bailey v. Drexel Furniture Co., 259 U.S. 20(1922).

105. Id. at 34-35.

106. Id. at 36-44.

107. United States v. Butler, 297 U.S. 1 (1936) (striking down as unconstitutional the Agricultural Adjustment Act, 1933, which allowed the Secretary of Agriculture to limit the production of certain crops and impose taxes on the production in excess of these limits, as well as authorized grants to farmers to control production as a means of regulating prices).

108. Id.

109. See, e.g., Sonzinsky v. United States, 300 U.S. 506 (1937) (upholding excise taxes that might have a regulatory effect).

110. United States v. Sanchez, 340 U.S. 42 (1950). 
olate other constitutional rights. ${ }^{112}$

\section{The Power to Spend}

The Tax and Spending Clause noted above not only confers the power to tax, but also grants the power to spend. ${ }^{113}$ As seen before, the Court defers to Congress' determinations on how to spend the country's purse to provide for a common defense and general welfare. ${ }^{114}$ Like taxes, Congress is permitted to financially support actions Congress cannot directly regulate. ${ }^{115}$ Congress can also condition or place strings on its grants to State and local governments, including in areas Congress might not otherwise be able to regulate, if the conditions are expressly stated and are reasonably connected to the purpose of the spending program. ${ }^{116}$ For instance, Congress successfully attached to transportation funds the condition that the funds could only be received by States that prohibited the purchase or public possession of any alcoholic beverage to individuals who were less than twenty-one years of age. ${ }^{117}$ The Court noted the "financial inducement" in this case was a mere five percent and, therefore, was too small to have a coercive effect. ${ }^{118}$ Congress has the authority to selectively use its funds to encourage or discourage certain activities. ${ }^{119}$ The Court further determined the Spending Clause granted Congress the authority to protect Federal funds from bribery of State and local officials. ${ }^{120}$

\section{Taxing Sugary Drinks}

Recently, U.S. Senators have been considering taxing sugary drinks to generate revenue for our nation's health care system. ${ }^{121}$ A recent Kaiser

111. United States v. Kahriger, 345 U.S. 22 (1953).

112. See Leary v. United States, 395 U.S. 6 (1969) (finding Congress' attempt to use its taxing power to compel self-incrimination violated the Fifth Amendment); and Grosjean v. American Press Co., 297 U.S. 233 (1936) (striking down a tax on newspaper since it violated the First Amendment right to the freedom of the press).

113. U.S. CONST. art. $1, \S 8, \mathrm{cl} .1$.

114. See South Dakota v. Dole, 483 U.S. 203, 207 (1987); Buckley v. Valeo, 424 U.S. 1, 90 (1976); and Helvering, 301 U.S. at 640.

115. Butler, 297 U.S. at 65-66.

116. Compare Oklahoma v. U.S. Civil Service Commission, 330 U.S. 127 (1947) (permitting provision of the Federal Hatch Act that granted funds to States on the condition that a civil service program was adopted and limitations were imposed on the political activities of certain government workers); with Pennhurst State School and Hospital v. Halderman, 451 U.S. 1 (1981) (finding that Congress' attempt to deny a State Federal grant program funds because it violated an ambiguous condition is unconstitutional).

117. Dole, 483 U.S. at 203.

118. Id. at 211 .

119. See, e.g, Rust v. Sullivan, 500 U.S. 173 (1991) (determining that a regulation forbidding doctors in Federally funded family-planning facilities from providing abortion counseling did not violate the doctors' First Amendment rights).

120. Sabri v. United States, 541 U.S. 600 (2004).

121. Editorial, A Healthy Tax, N.Y. TIMES, June 3, 2009, at A26, available at 
Family Foundation report found the majority of Americans support taxes on unhealthy items or "sin taxes", especially if used to raise money for health care and prevention. ${ }^{122}$ Each year, Americans spend over " $\$ 50$ billon a year on nondiet sodas. ${ }^{123}$ Evidence suggests soft drink consumption is associated with increased energy intake, body weight, and risk for type 2 diabetes, along with decreased intakes of milk and calcium, amongst other nutrients. ${ }^{124}$ Taxes have been successfully levied on tobacco and alcohol, which played a role in reducing purchases and generating revenue to address these two public health issues. ${ }^{125}$ In the case of soda drinks, one study estimated that, for every ten percent increase in the price of soda drinks, consumption decreases by about eight percent. ${ }^{126}$ A penny-perounce excise tax in New York was estimated to generate over one billion dollars. $^{127}$

Several States, including Arkansas, have already imposed excise taxes or sales taxes on sugared beverages and/or snack foods. ${ }^{128}$ A January 2007 report noted tax approaches at the State level varied by retail location (e.g., grocery store vs. vending machine) and by products (e.g., soft drinks vs. snack foods). ${ }^{129}$ States tended to tax vended snacks and soft drinks more

http://www.nytimes.com/2009/06/03/opinion/03weds3.html (last visited Mar. 5, 2010).

122. Kaiser Family Foundation, Kaiser Health Tracking Poll: Public Opinion on Health Care Issues, April 2009, http://www.kff.org/kaiserpolls/upload/7891.pdf (last visited June 10, 2009).

123. Editorial, supra note 121.

124. Lenny R. Vartanian, et al., Effects of Soft Drink Consumption on Nutrition and Health: A Systematic Review and Meta-Analysis, 97 AM. J. PUB. HeAlth 667, 667-75 (2007).

125. See Christopher Carpenter \& Phillp J. Cook, Cigarette Taxes and Youth Smoking: New Evidence from National, State, and Local Youth Risk Behavior Surveys, 27 J. HEALTH ECON. 287, 287-99 (2008) (reviewing national data from the 1991 to 2005 waves of the Youth Risk Behavior Surveys, including State and local field survey results, and finding that the large State tobacco tax increases of the past 15 years were associated with significant reductions in smoking participation and frequent smoking by youths); Phillp DeCicca, et al., Cigarette Taxes and the Transition from Youth to Adult Smoking: Smoking Initiation, Cessation, and Participation, 27 J. HEALTH ECON. 904, 904-17 (2009) (using data from the 1992 wave of the National Education Longitudinal Study to report no evidence that higher taxes prevent smoking initiation, but some evidence that higher taxes are associated with increased cessation); and Alexander C. Wagenaar, et al., Effects of Beverage Alcohol Price and Tax Levels on Drinking: A Meta-Analysis of 1003 Estimates From 112 Studies, 104 ADDICTION $179,179-90$ (2009) (reviewing the literature to determine that alcohol prices and taxes are related inversely to drinking).

126. Kelly D. Brownell \& Thomas R. Frieden, Ounces of Prevention-The Public Policy Case for Taxes on Sugared Beverages, 360 NEw ENG. J. MED. 1805, 1806 (2009).

127. Id.

128. Compare Brownell \& Frieden, supra note 126, at 1805 (notes 40 States tax sugary drinks or snacks); with Jason M. Fletcher, et al., Can Soft Drink Taxes Reduce Population Weight? (2008), available at http://www.economics.emory.edu/Working_Papers/wp/2008wp/ Frisvold_08_08_paper.pdf (last visited June 10,2009) (discussing how "[n] early two-thirds of all States currently tax soft drinks using excise taxes, sales taxes, or special exemptions to food exemptions from sales taxes to reduce consumption of this product, raise revenue, and improve public health").

129. Jamie F. Chriqui, et al., State Sales Tax Rates for Soft Drinks and Snacks Sold Through Grocery Stores and Vending Machines, 29 J. PUB. HEALTH POL'Y 226, 226-49 
aggressively than grocery items. Products; such as soft drinks, candy, and gum, were taxed higher than other foods and beverages. ${ }^{130}$ Yet, New York set aside an eighteen percent tax on sugary drinks after lobbyists claimed the tax would unfairly burden low-income families. ${ }^{131}$ Others oppose taxing soda or "junk food" for various reasons: people must eat, one category of food should not be singled out as bad, government should stay out of private behavior, and making certain foods more expensive will not significantly reduce obesity rates. ${ }^{132}$ Richard Postner, Judge on the United States Court of Appeals for the Seventh Circuit, discussed a variety of tax approaches relevant to obesity and suggested these tax approaches might be more expensive to enforce than effective at reducing obesity. ${ }^{133}$

Despite this opposition, the Federal government could tax unhealthy foods and beverages to deter consumption and generate revenue for health care and prevention. In order to be successful, Congress should ensure the tax does not unfairly burden any group of Americans nor make eating a healthy diet unaffordable for any Americans. The food and/or beverage categories taxed should be clearly defined and chosen based on strong evidence linking them to poor health outcomes. Caution should be given to not unduly burden one industry and efforts should be made to discuss feasible strategies with affected industries. The Federal tax should be shared equally across the States. Alternatively or in addition, the government could consider taxing food outlets with a high ratio of unhealthy to healthy items available in their stores. Taxes might be considered on harmful production practices or corporations that heavily market foods of lowernutrient quality. The threat of these taxes or the taxes themselves may encourage product reformulation. The Federal government could also or alternatively reduce income taxes imposed on corporations, farms, corner stores, or restaurants meeting certain benchmarks, such as distributing healthy products at a loss to corner stores or serving fresh fruits and vegetables with each of their main entrees.

\section{Tax Revenues}

If the Federal government imposed any form of these taxes, the funds generated should feed directly back into improving our food environment. A number of worthy initiatives could benefit from Federal support, includ-

(2008).

130. Id.

131. Editorial, supra note 121.

132. YAle University RUdD Center For Food Policy and OBesity, Soft DRINK TAXES, A POLICY BRIEF, 6 (2009), available at http://www.yaleruddcenter.org/resources/upload/ docs/what/reports/RuddReportSofDDrinkTaxMay2009.pdf(last visited June 8, 2009).

133. Tomas Philipson \& Richard Posner, Is the Obesity Epidemic a Public Health Problem? A Decade of Research on the Economics of Obesity, NBER WORKING PAPER SERIES No. 14010, 7-8 (2008), available at http://www.nber.org/papers/w14010.pdf (last visited October 15, 2009). 
ing: farmer's markets, farmstands, community-supported agriculture farms, small and mid-sized farms, and urban farms. ${ }^{134}$ The government should also consider using these funds to create incentive programs. ${ }^{135}$ For instance, incentives and/or competitive matching programs may help: (1) corporations and farmers develop creative, cost-effective ways to increase access to healthy foods, such as fruits and vegetables, in low-income communities; (2) growers produce more healthful products and use more sustainable production methods; (3) retailers change the profile of unhealthy to healthy foods available on their shelves and to purchase equipment and promotional materials necessary to purchase and sell healthy foods; (4) smaller stores to collaborate and invest in regional distribution systems that will allow for off-site storage and easy access to fresh fruits and vegetables and low-fat dairy products; (5) local and State governments work with local stores and corporations to create local and regional infrastructural systems to facilitate the year-round distribution of healthy foods; (6) the creation and further coordination between and among local, State, Tribal, regional, national, and global food policy councils; and (7) educational loan repayment programs geared towards professionals who have committed at least two years to improving food access in at-risk communities-whether on the farm, at a farmer's market, or in a local corner store. ${ }^{136}$ Likewise, Congress could consider anyone of these examples or others and establish related conditions (e.g., benchmarks for the ratio of healthy to unhealthy foods on corner store shelves or percent of production focused on healthy foods using sustainable practices) on which the local or State public or private entity would have to meet in order to receive funding.

Food environment research should receive a consistent, annual allocation and have flexible funding cycles able to support evaluations of naturally evolving environmental and policy changes. Some examples of questions meriting attention include: (1) what are the most cost-economic approaches in the short and long term to distribute fruits and vegetables to smaller corners stores in urban settings and to smaller grocery or convenience stores in rural settings, and, if and how, can Federal technical assistance improve access to healthy foods in corner stores; (2) what are the relationships between crop prices, food prices, food consumption, and health outcomes and how does socioeconomic status, race/ethnicity, and geography factor into these relationships; (3) what are the most effective strategies to ensure both USDA and HHS align to advance food, nutrition, and health goals to promote healthy Americans in all communities; for instance, ensuring government agricultural support complements U.S. Dietary

134. Harvie, et al., supra note 93 , at $419-23$.

135. Id.

136. David Wallinga, et al., Considering the Contribution of US Agricultural Policy to the Obesity Epidemic: Overview and Opportunities, 4 J. HUNGER \& ENVTL. NUTRITION 3, 13-16 (2009). 
Guidelines; (4) what "best practices" or adoptions to Federal food assistance programs, such as SNAP, will enable the government throughout the month to help support the production, purchase, and consumption of healthy foods; and (5) what are the most effective strategies for disseminating food environment assessments and possible evidence-based solutions to policymakers, communities, and public health and food systems professionals in public and private sectors. ${ }^{137}$

\section{Summarizing the Potential of Tax and Spend Powers on the U.S. Food System}

Therefore, the Tax and Spend Clause permits great latitude for Congress to consider how to raise and spend funds related to improving the U.S. food system. If new taxes are imposed on the food system, measures should be put in place to ensure tax revenues are spent to promote healthy eating and improve our nation's food systems.

\section{FROM PRODUCTION TO PROMOTION}

This section highlights the Federal legal and policy strategies with greatest impact on the food environment from production to promotion. In addition, this section explains barriers that have hindered the enactment of legal and policy strategies or could potentially present obstacles to using certain strategies to improve access to healthy foods across all U.S. communities.

\section{A. Farm Bill}

The U.S. Farm Bill is the most significant bill relating to agriculture production and food distribution. ${ }^{138}$ Originally authorized in 1949, the Farm Bill pulls together a range of separate laws relating to agriculture, although not all (e.g., immigration). ${ }^{139}$ These bills are categorized under the following titles: farm payments, agricultural trade, conservation, food assistance, agricultural production, credit, rural development, and research

137. Id. at 13-16; see also Healthy Eating Active Living Convergence Partnership, Promising Strategies for Creating Healthy Eating and Active Living ENVIRONMENTS, (2008), available at http:/www.convergencepartnership.org/atf/cf/ \%7B245A9B44-6DED-4ABD-A392-AE583809E350\%7D/CP_Promising\%20Strategies printed.pdf (last visited May 15, 2010); and Karen Glanz \& Amy Yaroch, Strategies for Increasing Fruit and Vegetable Intake in Grocery Stores and Communities: Policy, Pricing, and Environmental Change, 39 Preventive Med. S75, S75-80 (2004). (2006).

138. GEOFFREY S. BECKER, CRS REPORT FOR CONGRESS: THE "FARM BILL" IN BRIEF

139. Id. at 2-3. 
and education. $^{140}$

In 2008, the most recent Farm Bill was authorized, containing agricultural subsidies for foods, such as milk and beet sugar, but not for fresh fruits and vegetables. ${ }^{141}$ The bill also appropriated $\$ 500,000$ for a study on food deserts, defined in the bill as "an area in the United States with limited access to affordable and nutritious foods, particularly such an area composed of predominantly lower-income neighborhoods and communities."142 In June 2009, a report was released explaining a small percentage of consumers are constrained in their ability to access affordable nutritious foods. ${ }^{143}$ In urban settings, areas with limited access tended to be racially and economically segregated. ${ }^{144}$ Rural areas lacked transportation infrastructure to support easy access to affordable, nutritious food sources. ${ }^{145}$ The report noted easy access to all foods is important to understanding the growing obesity epidemic, not just limited access to specific healthy foods. ${ }^{146}$

A number of other provisions in the Farm Bill aim to increase access to healthy foods, particularly in low-income and ethnic minority communities. ${ }^{147}$ As one example, the 2008 Farm Bill expanded the USDA Fresh

140. Id.

141. Food, Conservation, and Energy Act of 2008, Pub. L. No. 110-234, $\$ \$ 1501$ and 1401, 122 Stat. 923, 990 and 977 (2008) (enacted to provide the continuation of agricultural programs through fiscal year 2012, amongst other purposes).

142. Id. at $\$ 7527,122$ Stat. at $1277-78$ (stating that the Secretary of Agriculture is to coordinate and consult with the Secretary of Health and Human Services, the Administrator of the Small Business Administration, the Institute of Medicine, and representatives of appropriate businesses, academic institutions, and non-profit and faith-based organizations the food desert report shall: (1) assess the incidence and prevalence of food deserts; (2) identify - (A) characteristics and factors causing and influencing food deserts; and (B) the effect on local populations of limited access to affordable and nutritious foods; and (3) provide recommendations for addressing the causes and effects of food deserts through measures that include-(A) community and economic development initiatives; (B) incentives for retail food market development, including supermarkets, small grocery stores, and farmer's markets; and (C) improvements to Federal food assistance and nutrition education programs[;]

and the report should be submitted to Congress not later than 1 year after the date of the enactment of this Act).

143. United States DePartment OF Agriculture, ACcess to AFFordable NUTRITIOUS FOOD: MEASURING AND UNDERSTANDING FOOD DESERTS AND THEIR CONSEQUENCES (2009), available at http://www.ers.usda.gov/Publications/AP/AP036/ AP036.pdf (last visited October 16, 2009).

144. Id. at $39-47$.

145. Id.

146. Id. at 47.

147. Northeast-Midwest Institute, "Local" Foods Initiatives in the Food, Conservation, and Energy Act of 2008, http://www.nemw.org (last visited June 8, 2009) (listing the following provisions as initiatives to increase access to local foods, especially in at-risk communities: Local Preference for School Food Purchases, allowing schools the ability to specify 
Fruit and Vegetable Snack Program in Schools, which may help reduce participants' purchases at corner stores after school. ${ }^{148}$ Changes were also made making it easier for schools to procure local foods, which may indirectly increase other local food venues access to local products. ${ }^{149}$. Findings from the food desert study and evaluations of the recent changes enacted will hopefully shape the next reauthorization of the Farm Bill, including alternative approaches to subsidies, and support further actions to improve the U.S. food system from farm to fork.

\section{B. Healthy Food Financing Initiatives}

The current President and his Administration, along with the First Lady have launched a number of activities to improve access to healthy eating in America, ranging from a Presidential Task Force on Childhood Obesi$\operatorname{ty}^{150}$ to the First Lady's Let's Move Campaign. ${ }^{151}$ The most aggressive ef-

"local" as a bid requirement $(\$ 4302)$; Farmers' Market Promotion Program, providing "up to $\$ 75,000$ to promote farmers' markets" ( $\$ 10106)$; Financing for Local Food Enterprises, "establish[ing] a prioritized pathway for entities involved in local food distribution and marketing to secure private-secure loans backed by a USDA loan guarantee"( $\$ 6015)$; Healthy Urban Food Enterprise Development Center, "establish[ing] a Center within Cooperatives State, Education, Extension, and Research Service to provide outreach, technical assistance, and feasibility study grants to support the development of enterprises which distribute and market healthy and locally produced foods to underserved urban, rural, and [T]ribal communities" ( $\$ 4402(2))$; Community Food Projects, matching "one-time, fifty percent grants...for community-based organizations to develop innovative solutions to address" food access issues, amongst other things $(\S \S 4402(1)$ \& 4406(a)(7)); Value-Added Agricultural Market Development Program Grants, continuing the existing "program with a priority for value-chains which market and distribute locally produced food and agricultural products" (\$6202); Senior Farmers Market Nutrition Programs, expanding funds to "allow currently unfunded [S]tates and [T]ribes to participate [and t]o increase benefits to existing participants ( $\$ 4231$ \& 4406(c)(1)); Organic Conversion, Technical, and Education Assistance, establishing allowance for "organic practices and the conversation of organic production practices as...eligible...under the EQIP conservation program" ( $\$ 2503$ under $\S 1204 \mathrm{~B}(\mathrm{i})$ ); Rural Micro-enterprise Assistance Program, establishing assistance for "rural entrepreneurs in establishing new small businesses in rural sectors" ( $\$ 6022)$; and Farmland Protection Program, increasing funding over five years $(\$ 2401)$ ).

148. Food, Conservation, and Energy Act of 2008, $\$ 19$ (2008) (amending the Richard Russell National School Lunch Act by permanently authorizing the Fresh Fruit and Vegetable Program nationwide, consolidating all prior operations under Section 19, and increasing program funding).

149. Food, Conservation, and Energy Act of 2008, $\$ 4302$ (2008); and Memorandum from U.S. Dept. of Agriculture Food \& Nutrition Service to all Regional Directors of Special Nutrition Programs and all State Directors of Child Nutrition Programs (Nov. 13, 2008) (on file with Indiana Health Law Review), available at http://www.fns.usda.gov/cnd/governance/ Policy-Memos/2010/SP_08_CACFP_05_SFSP_06-2010_os.pdf (last visited May 15, 2010).

150. The White House, Office of the Press Secretary, Presidential Memorandum-Establishing a Task Force on Childhood Obesity (Feb. 9, 2010), available at http://www.whitehouse.gov/ thepress-office/presidential-memorandum-establishing-a-task-force-childhood-obesity (last visited Jun. 13, 2010).

151. First Lady Michelle Obama, Let's Move: America's Move to Raise a Healthier Generation of Kids (Feb. 9, 2010), available at http://www.letsmove.gov/ (last visited Jun. 13, 2010). 
fort to date specifically targeting limited access to healthy food is an over $\$ 400$ million Healthy Food Financing Initiative. ${ }^{152}$ Part of the President's Budget for 2011, the Healthy Food Financing Initiative supports grocery stores and other healthy food retailers to operate in under-served urban and rural communities. ${ }^{153}$ Equipping existing stores to sell healthy foods is part of the initiative. ${ }^{154}$ Job creation is also a component. ${ }^{155}$ Local programs, such as in Philadelphia, Pennsylvania, and State initiatives, like those in Minnesota and Illinois, informed this new Federal investment. President Obama hopes financial and technical assistance from this U.S. Departments of Treasury, Agriculture, and Health and Human Services endeavor spark creative ways of increasing access to healthy foods in underserved communities from the private, non-for-profit, and other community development sectors. ${ }^{156}$ Another example of how USDA supports the flow of healthy, affordable foods into underserved areas is the Healthy Urban Food Enterprise Development Center ("HUFED"), which provides grants and technical assistance for entrepreneurs and communities. ${ }^{157}$ Recently, thirteen finalists were selected for grants out of a pool of 538 Letters of Interest. ${ }^{158}$ In Congress, the National Fresh Food Financing Initiative is garnering bi-partisan support and has been sent to the House Subcommittee on Rural Development, Biotechnology, Specialty Crops, and Foreign Agriculture for review to similarly support efforts from the private and non-forprofit sectors to open healthy food retail outlets in underserved communities. ${ }^{159}$

These financing initiatives illustrate how the Federal government can stimulate interest in using public-private-non-for-profit partnerships to increase access to healthy foods in underserved communities through grant programs and technical assistance. Learning from successful local and State programs and policies, the Federal government has started to demonstrate leadership in this area and help disseminate healthy food financing

152. Press Release, U.S. Treasury Department, Office of Public Affairs, Obama Administration Details Healthy Food Financing Initiative (Feb. 19, 2010), available at http://www.hhs.gov/news/press/2010pres/02/20100219a.html (last visited Jun. 13, 2010).

153. Id.

154. $I d$.

155. $I d$.

156. $I d$.

157. Wallace Center Winrock International, Healthy Urban Food Enterprise Development Center, available at $\mathrm{http}: / \mathrm{www}$.wallacecenter.org/our-work/current-initiatives/healthyurban-food-enterprise-development-center (last visited Jun. 13, 2010).

158. Id.

159. Recognizing the potential for a national fresh food financing initiative to provide an effective and economically sustainable solution to the problem of limited access to healthy foods in underserved urban, suburban, and rural low-income communities, while also improving health and stimulating local economic development, H.Res.975 $111^{\text {th }}$ Cong. (2009). 
initiatives throughout this country. Special attention is needed to ensure urban corner stores and smaller rural grocery stores benefit from these initiatives. Grants can help support the purchase and implementation of equipment and distribution networks to bring healthy, affordable foods to these smaller outlets while technical assistance can help disseminate successful promotion and pricing strategies. Building and equipping outlets is an important step to improving access to healthy eating within underserved communities but without complementary efforts to help these outlets sustain equitable access to healthy, affordable foods these initiatives will have little long-term impact. Equally as important, Federal nutrition education and promotion programs administered at USDA and HHS must work with relevant State and local stakeholders to ensure delivery of effective and consistent healthy eating messages and technical assistance. With adequate and sustainable support, USDA and HHS can help healthy food outlets sell healthy foods and consumers prepare and eat affordable, healthier items now available in their communities.

\section{Food Safety}

Federal food safety laws regulate our nation's food supply through a number of Federal agencies: USDA, HHS through both the Food and Drug Administration ("FDA") and the CDC, and the U.S. Environmental Protection Agency ("EPA"). ${ }^{160}$ Originally passed in 1906, the food safety laws are outdated, ${ }^{161}$ and recent initiatives aim to modernize our food safety system. $^{162}$ From peanut butter to spinach to pistachios, recent food safety

160. See Pure Food and Drug Act of 1906, 34 Stat. 768, 768-772 (1096) (preventing the manufacture, sale, transportation of adulterated or misbranded or poisonous or deleterious foods, drugs, medicines, and liquors, and for regulating traffic therein, and for other purposes); and Meat Inspection Acts, Pub. L. No. 90-201, 81 Stat. 584 (1906) (codified as amended at 21 U.S.C. $\$ 643$ (2010), amended by Pub. L. No. 59-242, 34 Stat. 1260 (1967) (mandating post-mortem inspection of every carcass, establishing sanitary standards for slaughter and processing plants, and requiring continuous USDA inspection of slaughter and processing operations).

161. See Caroline Smith DeWaal, Rising Imports, Bioterrorism, and the Food Supply, 59 Food \& DRUG L.J. 443, 433-39 (2004); and Sheila Fleischhacker, Comment, Food for Thought or Terror: The Legal Issues Surrounding Agroterrorism, 16 SAN JOAQUIN AGRI. L. REV. 79, 92-97 (2006-2007).

162. Food Safety Modernization Act of 2009, H.R. 875, 111th Cong. (2009) (assigning all the authorities and responsibilities of the Secretary of HHS related to food safety to the Administrator of Food Safety, who is to: (1) administer a national food safety program; and (2) "ensure that persons who produce, process, or distribute food...to prevent or minimize food safety hazards." Other duties include: (1) requiring food establishments to adopt preventive process controls; (2) enforcing performance standards for food safety; (3) establishing an inspection program; (4) strengthening and expanding foodborne illness surveillance systems; (5) requiring imported food to meet the same standards as U.S. food; and (6) establishing a national traceability system for food. In addition, the Administrator is required to: (1) identify priorities for food safety research and data collection; (2) maintain a DNA matching system and epidemiological system for foodborne illness identification, outbreaks, 
scares have forced farmers, food corporations, and small-scale vendors to reevaluate their liability. ${ }^{163}$ Small-sized farmers and corner store owners might be most at risk for absorbing the cost of liability insurance or for purchasing insurance that ends up not covering all their needs. ${ }^{164}$ For instance, a farmer may have insurance that does not cover her transactions at a farmer's market. ${ }^{165}$ A small vendor might not have adequate coverage for selling unpasteurized milk, even though his State allows selling raw goat milk. ${ }^{166}$

President Obama created a Food Safety Working Group in March 2009 and, in July 2009, this group submitted to the President three core food safety principles that should guide the development of a modern, coordinated food safety system: "(1) Preventing harm to consumers is our first priority; (2) Effective food safety inspections and enforcement depend on good data and analysis; [and] (3) Outbreaks of foodborne illness should be identified quickly and stopped." ${ }^{\text {"167 }}$ Subsequently, the President announced USDA and HHS individual and joint actions on salmonella, $E$. coli, national traceback and response system, along with the addition of new positions and the continuation of the Food Safety Working Group. ${ }^{168}$

These initial steps move the modernization of food safety forward, but continued reform is needed. Further work should consider the financial impacts current and new regulations may ultimately have on smaller-scale farms and small business vendors, ranging from documentation requirements for traceability to associated liability insurance tax credits.

and containment; (3) establish guidelines for a sampling system; (4) establish a national public education program on food safety; (5) conduct research on food safety; and (6) establish a working group on foodborne illness surveillance. The Act also requires the development of the Food-Borne Illness Health Registry and the reporting on the resources being dedicated to foodborne illness and food safety research. Other provisions are included, such as whistleblower protections and civil actions).

163. Marne Coit, Staff Attorney, Nat'l. Agricultural Law Center, University of Arkansas School of Law, Presentation at Farmers' Markets as a Community Collaboration Conference: Food Safety \& Vendor Liability (Feb. 6, 2009), available at http:// www.nationalaglawcenter.org (last visited June 9, 2009).

164. Press Release, Kathy Dahlkemper, Chairwoman, Subcomm. on Regulations and Healthcare of H. Comm. on Small Businesses, Food Recalls Hit Small Businesses Hard (Mar. 11, 2009) (on file with Indiana Health Law Review), available at http://www.house.gov/smbiz/PressReleases/2009/pr-3-11-09-food-recalls.html (last visited June 11, 2009).

165. Coit, Presentation, supra note 163.

166. Id.

167. Letter from Food Safety Working Group to President Barack Obama (July 2009), available at http://www.foodsafetyworkinggroup.gov/Home.htm (last visited October 15, 2009).

168. Press Release, The White House, Office of the Vice President, Obama Administration Delivers on Commitment to Upgrade U.S. Food Safety System (July 7, 2009) (on file with Indiana Health Law Review), available at http://www.whitehouse.gov/the press _office/ObamaAdministration-Delivers-on-Commitment-to-Upgrade-US-Food-Safety-System/ (last visited June 10,2010 ). 


\section{Child Nutrition Reauthorization}

Similar modernizing efforts aim to update school nutrition standards for foods and beverages sold outside the school meals to improve the school food environment. ${ }^{169}$ Congress should consider technological incentives for the development and promotion of healthier items in healthier sizes, which might ultimately end up in both schools and corner stores. ${ }^{170}$ Efforts should also be made to evaluate if and how the Federal government can help schools consolidate their purchasing and contract power to leverage their collective purchasing power to more effectively purchase a variety of healthy items at affordable prices and incentivize the development of more healthy items and promotional materials. ${ }^{171}$ Support should be granted to Team Nutrition Networks to coordinate approaches at the school and State level, including local efforts to work with corner stores and food corporations to ensure equal distribution of healthy foods. ${ }^{172}$

Congress should also consider ways to incentivize Local School Wellness Policies and associated policy councils to work within and outside the school doors to provide and promote healthy foods. ${ }^{173}$ The Local Wellness Policy 2004 mandate may have indirectly enabled schools an opportunity to address food marketing on school campus. ${ }^{174}$ The National Alliance for Nutrition and Activity ("NANA") advocates for Congress, through the Child Nutrition Reauthorization 2009, to require schools to explicitly address food marketing in schools. ${ }^{175}$

Outside of the school cafeteria, Congress should continue to evaluate the recent changes to the USDA Women, Infant, and Children (WIC) food package and consider further methods of increasing participant access and participation in farmers' markets. Efforts should be made to consider ways the Federal government can leverage its purchasing power through WIC, along with SNAP, to increase the availability of fruits and vegetables in urban corner stores and small rural and Tribal grocery stores. ${ }^{176}$ Further

169. Healthy, Hunger-Free Kids Act of 2010, S. 3307, $111^{\text {th }}$ Cong. (2009-2010); and Improving Nutrition for America's Children Act, H.R. $5504111^{\text {th }}$ Cong. (2009-2010).

170. Corinna Hawkes, Freelance Consultant, Presentation at the Robert Wood Johnson Foundation Health Eating Research Food Systems \& Public Health Conference: Leveraging the Food Supply Chain to Promote Healthy Diets and Prevent Obesity (Apr. 2, 2009).

171. Id.

172. SOCIETY FOR NUTRITION EDUCATION, RECOMMENDATIONS FOR IMPROVING Children's Nutrition EdUCATION AND Promotion: 2009 Child NUTRITION REAUTHORIZATION (2009) http://www.sne.org/documents/CNRUSDAsept52008_approved92008.pdf (last visited June 6, 2009).

173. Child Nutrition and WIC Reauthorization Act of 2004, Pub. L. No. 108-265, §204, 118 Stat. 780 (2004).

174. Id.

175. National Alliance for Nutrition \& Activity, Child Nutrition Reauthorization Recommendations, http://cspinet.org/new/pdf/cnr_recommendations_2009.pdf (last visited June 8, 2009).

176. Healthy Eating Active Living ConVERgence Partnership, supra note 137. 
work is needed to increase the breadth and depth of WIC and SNAP purchases through farmer's markets. This work will require outreach to vendors and farmers, along with educating and promoting these outlets to WIC and SNAP participants.

\section{E. Food Marketing}

In 2006, the Institute of Medicine ("IOM") reported food and beverage marketing influences children's dietary intakes and weight status and recommended both public and private sectors work on improving the promotion of healthy foods and beverages. ${ }^{177}$ In the 1970s, the Federal Trade Commission ("FTC") was unsuccessful in its attempt to regulate food marketing to children, because of constitutional limits on restricting commercial speech and political pressures. ${ }^{178}$ Nonetheless, President Obama could respond to the rising childhood obesity rates and work with Congress to curtail food marketing in certain public venues like schools, or regulate product placements in grocery or corner stores at children's eye-level. ${ }^{179}$ Developing government-industry strategies might be an effective approach to incentivize corporations to market healthy items and self-regulate themselves and their peers. Likewise, government small-business community organization partnerships could potentially facilitate the development of instore promotion of healthier items within corner stores.

In March 2009, President Obama requested research into whether or not the government should set standards for determining which foods are healthy and appropriate to market to children and adolescents as old as seventeen. ${ }^{180}$ The bill created a new Interagency Working Group on Food Marketed to Children, requiring representatives from the FTC, FDA, CDC, and USDA. ${ }^{181}$ This Group is charged with developing the report, deciding on which media outlets to address, and setting forth recommendations. ${ }^{182}$ The FTC has requested public comments and will be hosting a public form,

177. INSTITUTE OF MEDICINE, FOOD MARKETING TO CHILDREN AND YOUTH: THREAT OR OPPORTUNITY? 226-309, 373-388 (2006).

178. See Jennifer L. Harris, et al., A Crisis in the Marketplace: How Marketing Contributes to Childhood Obesity and What Can Be Done, 30 ANN. Rev. PUB. Health. 211, 219 (2009); and David S. Modzeleski, Note, Lorillard Tobacco v. Reilly: Are We Protecting the Integrity of the First Amendment and the Commercial Free Speech Doctrine at the Risk of Harming Our Youth?, 51 CATH. U. L. REV. 987, 987 (2002).

179. See Lee J. Munger, Comment: Is Ronald McDonald the Next Joe Camel? Regulating Fast Food Advertisements that Target Children in Light of the American Overweight and Obesity Epidemic, 3 CONN. PUB. INT. L.J. 456, 474 (2004) (discussing how the Court ruling in Lorillard Tobacco Co. v. Reilly, 533 U.S. 525 (2001), seemingly allows States or even schools the authority to regulate food marketing on school campuses).

180. Omnibus Appropriations Act of 2009, Pub. L. No. 111-8, 123 Stat. 524 (2009).

181. Id.

182. Id. 
entitled "Sizing Up Food Marketing and Childhood Obesity." "183 While the Working Group is scheduled to discuss some of their findings at the upcoming forum, ${ }^{184}$,the final report is expected by July $2010 .{ }^{185}$

\section{F. Nutrition Labeling}

The Nutrition Labeling Education Act (NLEA) grants the FDA the authority to require nutrition labeling of most of the foods regulated by the Agency. ${ }^{186}$ FDA also regulates all nutrition content claims (e.g., "low fat") and health claims (e.g., "prevents health disease"). ${ }^{187}$ The FDA has considered using its authority to improve front-of-package information to consumers about serving sizes and calories. ${ }^{188}$ Recently, FDA and CDC requested guidance from the IOM on front-of-package nutrition rating systems and symbols. ${ }^{189}$ Due in 2010 , information gleaned from this report may guide regulatory approaches and industry responses to use front-ofpackage nutrition rating systems and symbols to inform consumers in an accurate, consistent format about the nutritional quality of food and beverages items and the relationships between the item and health outcomes. In the meantime, certain food and beverage companies participate in the Children's Advertising Review Unit, an industry financed voluntary selfregulation program. ${ }^{190}$

Restaurants did not have to comply with NLEA. ${ }^{191}$ New York City over came legal challenges to defend their menu labeling law, which set the stage for other local, State, and, ultimately, the Federal government to fol-

183. Posting of Federal Trade Commission, FTC to Host Forum on Food Marketing to Children, http://www.ftc.gov/opa/2009/09/foodmarket.shtm (Sept. 29, 2009) (announcing a December 15, 2009 public forum hoping to bring together industry representatives, federal regulators, consumer groups, scientists, and legal scholars).

184. Id.

185. Omnibus Appropriations Act of 2009, Pub. L. No. 111-8, 123 Stat. 524 (2009).

186. Nutrition Labeling and Education Act of 1990, Pub. L. No. 101-535, 104 Stat. 2353 (1990) (codified at 21 U.S.C. $\$ 343$ ).

187. Id. at $\$ 3,104$ Stat. at $2357-60$.

188. Lauren M. Tarantino, Ph.D., Acting Director, Office of Nutritional Products, Labeling, and Dietary Supplements, Center for Food Safety and Applied Nutrition, Food and Drug Administration, Letter to Food Manufacturers about Accurate Serving Size Declaration on Food Products, Mar. 12, 2004, available at http://www.fda.gov/Food/LabelingNutrition/FoodLabelingGuidanceRegulatoryInformation/I nspectionCompliance/WarningOtherLetters/ucm1 10234.htm (last visited Jun. 11, 2010).

189. Institute of Medicine, Announcement: IOM Considers Front-of-Package Food Labeling, Dec. 2009, available at http://www.iom.edu/Global/News\%20Announcements/IOM-Considers-Front-of-PackageFood-Labeling.aspx (last visited Jun. 11, 2010).

190. Council of the Better Business Bureau, About the Children's Advertising Review Unit, available at http://www.caru.org/about/index.aspx (last visited Jun. 11, 2010).

191. Id. at $§ 2(\mathrm{a}), 104$ Stat. at 2353. 
low. ${ }^{192}$ Indeed, a mandatory menu labeling requirement was enacted during health care reform. ${ }^{193}$ This Federal law preempts ${ }^{194}$ local and State menu labeling ordinances. ${ }^{195}$ Even though the menu labeling law is based on a strong public health rationale and founded on consumer rights, ${ }^{196}$ further work is needed to understand the impact these policy changes have had (e.g., in New York) and will have (e.g., nationwide) on consumer behavior, dietary intakes, and health outcomes. ${ }^{197}$ Initial research on New York City's menu labeling ordinance found some positive effects on low-income consumer awareness, but not any significant impacts on caloric consumption. ${ }^{198}$ Researchers and policymakers need to consider a more holistic policy approach to the food environment and figure out the appropriate balance of initiatives targeting certain aspects of the food environment, such as fast food restaurants. Illustrative of this, an initial assessment of the Los Angeles ban on new construction of fast food restaurants in South Los Angeles did not find much of a positive impact on improving access to healthy eating. ${ }^{199}$ The ban evaluated did not address the area's exposure to conveni-

192. New York Department of Health and Mental Hygiene Board of Health, Notice of Adoption of AN AMENDMENT (\$81.50) TO ARTICLE 81 OF THE NEW YorK CitY HEALTH CODE, withstanding judicial challenge in Defendant's Memoradum of Law in Opposition to Plaintiff's Motion for Injunction Pending Appeal, New York State Restaurant Association v. New York City Board of Health, (S.D.N.Y. 2008) (No. 08 Civ. 1000), denied; and was informed by earlier successful challenge in New York Restaurant Association v. New York City Board of Health, 509 F. Suppl. 2d 351 (S.D.N.Y. 2007).

193. The Patient Protection and Affordable Care Act. Pub. L. No. 111-148, Sec. 4205 Nutrition Labeling of Standard Menu Items at Chain Restaurants (2010) (requiring chain restaurants with 20 or more outlets to provide calorie labeling on chain restaurant menus, menu boards, and drive-through displays, as well as on vending machines).

194. U.S. CoNST. art. VI, cl. 2 (also known as the Supremacy Clause, and resolving conflicts between the Federal government and a State government in favor of the Federal government, within its Constitutional parameters); see also McCulloch v. Maryland, 17 U.S. 316, 436 (1819) (explaining how State laws cannot interfere with the Federal Government, and Federal law preempts over inconsistent State action).

195. U.S. CONST. art. VI, cl. 2 (also known as the Supremacy Clause, and resolving conflicts between the Federal government and a State government in favor of the Federal government, within its Constitutional parameters); see also McCulloch v. Maryland, 17 U.S. 316, 436 (1819) (explaining how State laws cannot interfere with the Federal Government, and Federal law preempts over inconsistent State action).

196. Jennifer L. Pomeranz \& Kelly D. Brownell, Legal and Public Health Considerations Affecting the Success, Reach, and Impact of Menu-Labeling Law, 98 AM. J. PUB. HEALTH 1578, 1578 (2008).

197. Karen Glanz \& Deanna Hoelscher, Increasing Fruit and Vegetable Intake by Changing Environments, Policy, and Pricing: Restaurant-Based Research, Strategies, and Recommendations, 39 PREVENTIVE MED. S88, S88, S88-89 \& S91-92 (2004).

198. Brian Elbel, et al., Calorie Labeling and Food Choices: A First Look at the Effects on Low-Income People in New York City, 28 HEALTH AFF. w1110, w1110, w1114 \& w1115 (2009).

199. Roland Sturm \& Deborah A. Cohen, Zoning for Health? The Year-Old Ban on New Fast-Food Restaurants in South LA, 28 HEALTH AFF. w1088, w1088-97 (2009). 
ence stores ${ }^{200}$, which evidence suggests account for a significant amount of children's food purchases and daily caloric intake. ${ }^{201}$

\section{G. Other Federal Options}

A number of other Federal laws directly or indirectly affect the food environment. $^{202}$ One receiving some attention from the public health law community is the Takings Clause of the Fifth Amendment (incorporated into the Fourteenth Amendment), permitting the Federal, State, or local governments to take private property for public use if the government pays the owner just compensation. ${ }^{203}$ The Court's interpretation of "public use" is broad. $^{204}$ Moreover, the Court determination of a taking requiring just compensation can be less than $1 / 2$ inch in diameter of an apartment building. ${ }^{205}$ Physical invasion is not needed, since a regulation-even if temporary, diminishing the value of a property could be deemed a taking requiring just compensation. ${ }^{206}$ Recent Courts have been reluctant to find regulatory takings, though. ${ }^{207}$ To protect the public's health, the government generally has the authority to take, destroy, or restrict the use of private property. ${ }^{208}$ Even when protecting the public's health, Phillp Morris, Inc. v. Harshbarger illustrates there are limits to the States' authority. ${ }^{209}$ In Phillp Morris, a Massachusetts law requiring cigarette manufacturers to report product ingredients was preliminarily enjoined since the regulation

200. Los Angeles City Councll, Office of tHe City Clerk, Council File No. 071658(2008),available at http://cityclerk.lacity.org/lacityclerkconnect/index.cfm? $\mathrm{fa}=$ ccfi.viewrecord\& cfnumber $=07-1658 \&$ CFID $=14393210 \&$ CFTOKEN $=57$ e690e22f3c5bld-687ED883-C32A-17133AE34ECB63B5F02F\&jsessionid=f03076666133f6884364485b2d5b4c17336f (last visited Jun. 10, 2010).

201. Kelley E. Borradaile, et al., Snacking in Children: The Role of Urban Corner Stores, 124 PEDIATRICS 1294, 1292-1297 (2009).

202. Gostin, et al., supra note 34, at 30.

203. U.S. CONST. amend. V; see also Chicago, Burlington, \& Quincy R.R. Co. v. Chicago, 166 U.S. 226 (1897) (incorporating the protection of economic rights into the Fourteenth Amendment).

204. Hawaii Housing Authority v. Midkiff, 467 U.S. 229, 240-41 (1984).

205. Loretto v. Teleprompter Manhattan CATV Corp., 458 U.S. 419 (1982).

206. First English Evangelical Lutheran Church v. County of Los Angeles, 482 U.S. 304 (1987).

207. See, e.g. Keystone Bituminous Coal Ass'n v. DeBenedictis, 480 U.S. 470, 506 (1987) (denying a takings challenge even though significant amounts of coal were required to be left un-mined as surface support for structures on top of the coal mines, because the regulation did not make mining "commercially impracticable"); and Tahoe-Sierra Preservations Council, Inc. v. Tahoe Regional Planning Agency, 535 U.S. 302 (2002) (finding a government order prohibiting development during the creation of a comprehensive land-use plan did not constitute a "per se taking of property requiring compensation").

208. RICHARD GOODMAN, ET AL., LAW IN PUBLIC HEALTH PRACTICE 202204 (Oxford University Press 2003).

209. Id. at 204; see also Philip Morris, Inc. v. Harshbarger, 159 F.3d 670 (1st Cir. 1998). 
would unconstitutionally obtain trade secrets. ${ }^{210}$

If the government attempted to require corner stores to allocate a number of shelves or certain child-eye-level shelves to fresh fruits and vegetables, corner stores could potentially challenge the government's action as a taking requiring just compensation. Nonetheless, if the regulatory taking was minimal, and the stores could remain profitable, the Court would likely not find the government took the shelf space nor require the government to pay just compensation for the space. Even though this power may exist, invading private property might not be the most effective course to encourage buy-in from local corner stores. A more worthwhile Federal investment could be technical assistance to States and local governments on model land use and zoning ordinances to establish and adequately support farmer's markets and community gardens, offering both residents and corner store owners consistent access to affordable, healthy foods. ${ }^{211}$

Another potential Federal option is the Safe Accountable Flexible Efficient Transportation Equity Act (SAFETEA), which could potentially provide funding for the development and maintenance of safe routes for customers to walk and bike to local food outlets. ${ }^{212}$ Reassessing the U.S. and global antitrust regulations continues to be a possible, yet challenging avenue to reduce the concentration of agriculture and increase local access to food production. ${ }^{213}$ The American Recovery and Reinvestment Act of

210. Philip Morris, 159 F.3d at 675-78.

211. Leadership for Healthy Communities, Action Strategies Toolkit: A guide for Local and State Leaders Working to Create Healthy Communities and Prevent Childhood Obesity, May 2009, available at http:/www.leadershipforhealthycommunities.org/images/stories/toolkit/ action_strategies_toolkit_final\%5B1\%5D.pdf (last visited Jun. 11, 2010); and National Policy and Legal Analysis Network to Prevent Childhood Obesity, Establishing Land Use Protections for Farmer s Makets,Dec.2009,availableathttp://www.nplanonlie.org/system/files/nplan/Establishing\%20 Land\%20Use\%20Protections\%20for\%20Farmers\%27\%20Markets_FINAL_091203.pdf (last visited Jun. 10, 2010).

212. Safe, Accountable, Flexible, and Efficient Transportation Equity Act of 2005., Pub. L. No. 109-59, 119 Stat. 1248 (2005).

213. The Clayton Antitrust Act of 1914 , ch. 323,38 Stat. 730 (codified at 15 U.S.C. $\S$ 12 through 15 U.S.C. $§ 27$ and 29 U.S.C. $\$ 52$ and 29 U.S.C. $\$ 52$ and 29 U.S.C. §53) (exempting agricultural organizations, but otherwise regulating mergers and acquisitions, amongst other arrangements, that may have an anti-competitive effect); see also Harrison $\mathrm{M}$. Pittman, An National Law Center Research Article: Market Concentration, Horizontal Consolidation, and Vertical Integration in the Hog and Cattle Industries: Taking Stock of the Road Ahead, NAT'L. AGRIC. L. CTR. (2005), available at http://www.nationalaglawcenter.org (last visited June 10, 2009) (discussing the following cases to explain the judicial branches' role in addressing market concentration: Pickett v. Tyson Fresh Meats, Inc., 315 F.Supp.2d 1172 (M.D. Ala. 2004); London v. Fieldale Farms, Corp., 410 F.3d 1295 (11th Cir. 2005); South Dakota Farm Bureau, Inc. v. Hazeltine, 340 F.3d 583 (8th Cir. 2003), cert. denied, 124 S.Ct. 2095 (2004); and Smithfield Foods, Inc. v. Miller, 367 F.3d 1061 (8th Cir. 2004)); and Jon Lauck, An National Agricultural Law Center Research Article, Concentration Concerns in the American Livestock Sector: Another Look at the Packers and Stockyards Act, NAT'L. AGRIC. L. CTR. (2004), available at http://www.nationalaglawcenter.org (last visited June 10, 2009) (analyzing the past, current, and potential roles of the Packers and Stockyard Act on 
2009 awarded more than $\$ 119$ million to States and U.S. territories, which can be used to support environmental and policy approaches to improving access to healthier foods in underserved communities. ${ }^{214}$ President Obama is also working with The White House Offices of Management and Budget and Health Reform and U.S. General Services Administration to deliver healthier foods to Federal employees. ${ }^{215}$ By building a template for healthier food service contracts, Obama's Administration hopes to provide a model of how other worksites, schools, and childcare settings can improve the nutritional quality of their food and beverage offerings. These contracts may also stimulate healthier product development and promotion strategies from the food service sector, as well as the food and beverage industry. Collectively, these diverse Federal options provide food for thought on the breadth and depth of authority and approaches the Federal government can utilize to improve access to healthy foods in America.

\section{CONCLUSION}

A cornucopia of Federal policies can facilitate improvements in the U.S. food systems and address healthy food access disparities at the local and shelf levels. Barriers-ranging from political, legal, social, and financial-may impede the enactment or the full potential of these bills. This Article explained a variety of facilitators and barriers to stocking healthier food and beverage options, with particular emphasis on urban corner stores or small rural stores. This Article is not exhaustive, but should guide the development of a future grocery list of the most effective and feasible actions the Federal government can take to address food, health, and environmental issues and inequalities within the local food environment.

As President Obama works on addressing access to health care, efforts should be made to communicate with his Administration regarding their current and potential authorities to advance healthy U.S. food systems. Hopefully, this Administration will facilitate and support cross-Agency initiatives, pulling together agriculture, health, planning, commerce, energy, education, and environmental protection, amongst other sectors to more effectively and creatively collaborate to link agriculture, health, sustainability, and economic development. ${ }^{216}$

de-concentrating American livestock).

214. Centers for Disease Control and Prevention, Communities Putting Prevention to Work, available at http://www.cdc.gov/chronicdisease/recovery/community.htm (last visited Jun. 13, 2010).

215. Press Release, U.S. General Services Administration, GSA to Provide Healthier

Food Choices to Federal Employees (Feb. 10, 2010), available at http://www.gsa.gov/Portal/gsa/ep/contentView.do?contentType=GSA_BASIC\&contentId=2 9091 (last visited Jun. 13, 2010).

216. Mary Story, et al., Food Systems and Public Health: Linkages to Achieve Healthier Diets and Healthier Communities, 4 J. HUNGER \& ENVTL. NUTRITION 219, 223 (2009). 
Increasing access to healthy foods requires a range of Federal, Tribal, State, and local legal and policies strategies. This Article only focuses on Federal possibilities. Throughout the development, implementation, and evaluation of potential Federal food environment initiatives, the Federal government should involve multiple stakeholders, ranging from farmers to food and beverage corporations to public health professionals to regional planners to policymakers to store owners to citizens. Federal strategies should complement local, State, and Tribal efforts to enhance the capacity of each government level to facilitate and not impede the sale of carrots and other healthy items on the shelves of urban corner stores and smaller rural and Tribal grocery stores throughout this country. 